\title{
Authors of Articles and Book Reviews in Vol. 8 No. 3
}

BRIAN BENNETT, Chairman of the Anglo-Belarusian Society, Former British Ambassador to Belarus, London, United Kingdom, brian_m_bennett@yahoo.co.uk

THOMAS M. BOHN, PhD in History, Professor of the history of Eastern Europe, Historical Institute, Justus-Liebig-University, Gießen, Germany, thomas. bohn@geschichte.uni-giessen.de

ADAM COMAN, PhD candidate, Department of Historical Sociology, Faculty of Humanities, Charles University, Prague, Czech Republic, adam.coman@gmail.com

RAYK EINAX, PhD in History, Historical Institute, Justus-Liebig-University, Gießen, Germany, rayk.einax@geschichte.uni-giessen.de

ALIAKSANDR HUŽALOǓSKI (ALIAKSANDR HUZHALOUSKI), PhD, Professor of the Museum Studies Programme, Belarusian State University, Minsk, Belarus, huzhalouski@gmail.com

DANIELA KOLENOVSKÁ, PhD, Researcher at the Institute of Contemporary History, Department of global conflicts and their consequences, Academy of Sciences of the Czech Republic, Prague, kolenovska@seznam.cz

ALENA MARKOVÁ, PhD, Assistant Professor, Department of Historical Sociology, Faculty of Humanities, Charles University, Prague, Czech Republic, alena.markova@fhs.cuni.cz

ARNOLD MCMILLIN, PhD, Emeritus Professor, School of Slavonic and Eastern European Studies, University College London, United Kingdom, a.momillin@ucl.ac.uk

ANGELIKA POBEDONOSTSEVA KAYA, PhD, Saint Petersburg State University, Faculty of Asian and African Studies, Russian Federation, a.pobedonostseva@spbu.ru 